\title{
EFFICIENCY IN THE FISCAL OPERATIONS OF CITIES
}

\author{
By Edmund D. Fisher,
}

President of the National Association of Comptrollers and Accounting Officers, and Deputy Comptroller City of New York.

Efficiency is a relative term. Accomplishment in municipal administration is more or less restricted by the lack of standards of efficiency under civil service and by the lack of continuity of management, as well as through the inherent political distraction of official life.

Much, however, has been accomplished in the various cities of the country during the last decade-partly through the awakening of civic interest impelled by the high costs resulting from municipal extravagance, and partly through the co-operation of civic organizations such as bureaus of municipal research, citizens' unions, and national associations and leagues such as the National Municipal League and the National Association of Comptrollers and Accounting Officers.

This article, however, will refer only to some of the newer methods of financing adopted by Hon. William A. Prendergast, comptroller of the City of New York, who has developed the principle of efficiency in municipal administration with the vigor and intelligence of an experienced business man. As the annual movement of the receipts and disbursements of the City of New York is over half a billion dollars, the importance of its finances in domestic and international relations is apparent.

As the basis for administrative and financial reform, the comptroller had prepared for departmental and public use a clear and comprehensive statement of the actual condition of the city's finances at the time he took office. This statement outlined, first, a definite policy of funding amounts borrowed against uncollectible taxes, and providing for their cancellation partly by issues of corporate stock and partly through annual instalments in the budget to be raised by taxation, and, second, the policy of separating money borrowed for public improvements from money borrowed in anticipation of current revenues; thus preventing the use of corporate stock (bond) funds for

(71) 
current purposes. The best evidence of the effect of this cleaning-up policy is the fact that, while on January 1,1910 , there were $\$ 60$,000,000 outstanding in revenue bonds, the amount outstanding on January 1, 1912, was but $\$ 47,600,000$, or a reduction of $\$ 12,600,000$; and this notwithstanding the rapid growth of the city's business and the fact that its annual current requirements increased by at least $\$ 10,000,000$ during the period mentioned.

As financing the city's public improvements-and current needs is among the most important functions of the comptroller and involves the borrowing of large sums of money, attention was first devoted to correcting certain disadvantageous practices which have existed in New York City's financial management since its organization. Perhaps the greatest evil which prevailed was the necessity of borrowing money in anticipation of the collection of taxes which were not due under the law until more than nine months after the beginning of the fiscal year. In 1910 the borrowing and re-borrowing for this purpose aggregated $\$ 200,000,000$. In 1909 one of the chief items of current expenses was the interest for such anticipatory borrowing, which in that year amounted to $\$ 5,200,000$.

In the spring of 1910 a measure was introduced by the comptroller in the New York State legislature, permitting the issuance of what have become known as "Revenue Bills," which are practically equivalent to revenue bonds or revenue warrants. This new form made possible the borrowing of money in London or Paris, frequently at much lower rates than were obtainable in American markets. This principle also affords an occasional opportunity of realizing profits on exchange. The total amount of such borrowings abroad during the year 1911 was approximately $\$ 38,500,000$, which, expressed in terms of foreign currency, amounted to $120,000,000$ francs and 3,200,000 pounds sterling. The condition of the exchange markets during the past year was such that, in borrowing sterling abroad, exchange was sold at a rate sufficiently high, namely, 4.8650, to permit of the purchase of a "cover" for fall delivery at 4.8550 , being a profit of one cent to the pound. In this way a saving of $\$ 20,000$ was effected and the average rate of sterling borrowing was reduced from $3 \frac{1}{4}$ to 2.95 per cent.

As it is also necessary to finance tax arrearages, it is at all times practicable to renew items where exchange is not sufficiently advantageous to make payment of maturing bills desirable. During the 
month of December, 1911, foreign maturities aggregating $\$ 7,000,000$ were so renewed, with the general result in international relations involved as in effect to correspondingly strengthen this country's reserves. Partially because of this new financial policy and partly by reason of cautious borrowing, the annual interest account of the city has been reduced from its 1909 "high-water mark" of $\$ 5,200,000$ to the comparatively low annual charge for this purpose in 1911 of $\$ 3,800,000$, notwithstanding an increasing volume of business.

The law which fostered this enormous amount of anticipatory borrowing, however, was manifestly unsound. Consequently, in 1910 , an investigation of the methods of collecting taxes in various American cities was initiated. Out of thirty cities interviewed concerning the subject it was found that eight, Cleveland, Baltimore, Kansas City, Indianapolis, Los Angeles, Fort Wayne, Topeka and Washington, D. C., were collecting on the semi-annual basis, and that the average date for the collection of taxes was about four months after the beginning of the fiscal year. In many cases collections are made as soon as thirty days thereafter. It was also found, through correspondence with authorities abroad, that, in London, municipal rates (taxes) are levied half-yearly, in advance, and in some districts an option is given whereby payment may be made quarterly. This is regarded as a special privilege and is particularly desired by the people. The custom of levying rates (taxes) half-yearly is also in vogue in the British provinces.

Attempting to change the habits of the great City of New York in this respect seemed rather a huge task at the outset, but the work was begun and consummated. The technical language of the act adopted for the semi-annual collection of taxes follows:

All taxes upon personal property and one-half of all taxes upon real estate shall be due and payable on the first day of May and the remaining and final one-half of taxes on real estate shall be due and payable on the first day of November. All taxes shall be and become liens on the real estate affected thereby on the respective days when they become due and payable as hereinbefore provided and shall remain such liens until paid.

The second half of the tax on real estate which is due as hereinbefore provided on the first day of November following the payment of the first half may be paid on the first day of May or at any time thereafter, providing the first half shall have been paid or shall be paid at the same time, and on such payments of the second half as may be made in such manner prior to November first a discount shall be allowed from the date of payment to November first at the rate of four per centum per annum. 
Another change in the method of financing municipal requirements which has proven particularly advantageous to the City of New York is the marketing of corporate stock (bonds), so far as practicahle, through but a single sale in any one year. This practice affords the bankers and brokers, who are practically the chief bidders at corporate stock sales, ample opportunity to market the securities so purchased without fear of the depreciating tendency of frequent sales. Large sales, however, necessitate large bank balances during the period of disbursement, with the consequent loss of interest. Partly for this reason and partly to secure flexibility in financing, legislation was enacted which authorized the comptroller to issue what are known as "corporate stock notes." The provisions covering their issue are as follows:

The comptroller is authorized to issue, whenever he may deem it for the best interests of the city so to do, bills or notes, hereinafter described as "notes," maturing within a period not to exceed one year, in anticipation of the sale of corporate stock duly authorized at the time such notes are issued. The proceeds of the sale of such notes shall be used only for the purposes for which may be used the proceeds of the sale of corporate stock in anticipation of the sale whereof the notes were issued. All of such notes and any renewals thereof shall be payable at a fixed time, and no renewal of any such note shall be issued after the sale of corporate stock in anticipation of which the original note was issued. In the event that a sale of such corporate stock shall not have occurred prior to such sale the comptroller shall, in order to meet the notes then maturing, issue renewal notes for such purpose. Every such ncte and renewal note shall be payable from the proceeds of the next succeeding sale of corporate stock. The total amount of such notes or renewals thereof issued and outstanding shall at no time exceed one-half of the total amount of corporate stock authorized to be issued and if no sale of corporate stock shall have been held within six months preceding the issue of such notes then the total amount of such notes or renewals thereof, issued and outstanding, shall at no time exceed one-half the total amount of corporate stock authorized to be issued on the date which shall be six months after such last preceding sale.

The Corporate Stock Note Bill provides, in effect, a short-time instrument analagous to the railroad note. It is estimated that the city will save approximately $\$ 1,000,000$ annually in interest through the operation of this bill. The comptroller is now in a position to have a sale of corporate stock at any time rates appear most favorable, when the volume of bills then outstanding will be automatically funded. These bills have recently been sold on a basis of approximately three per cent, whereas former corporate stock issues of the 
city are practically on a four per cent basis. By this temporary financing a saving of about one per cent was effected. This saving, of course, was possible only because of the city's unusually good credit and because money market conditions were exceptionally favorable. If rates were very high, however, the principle would be equally valuable, because a bond sale would be inexpedient.

There was also introduced in the legislature, in 1911, what is known as the "Foreign Sales Measure," the essential subject matter of which is as follows:

When in the opinion of the comptroller it shall appear desirable to have the whole or any part of an issue of corporate stock made payable in the currency of a country other than the United States, such corporate stock so to be sold shall be made payable in such currency, with certificates in such amounts, and sold in such manner as may be duly authorized by the commissioners of the sinking fund, provided, however, that in case such corporate stock payable in a foreign currency or currencies is not sold in the manner prescribed for the sale of corporate stock under the provisions of Section 182 of this Chapter (public bidding), the comptroller shall invite sealed, competitive tenders for the purchase of such corporate stock in such manner as the commissioners of the sinking fund shall prescribe; and he shall make award or awards to the highest bidder or bidders for such corporate stock with the full power to reject all bids. The proceeds of sales of such corporate stock shall be recorded in the books of the Finance Department in the terms of the currency of the United States, as well as in the terms of such foreign currency in which such corporate stock shall have been issued.

This legislation will permit the sale of corporate stock in European cities, and the bonds may be made payable both as to principal and interest in foreign currency. As yet there has been no test of this measure, no sale of corporate stock having been held for over a year. It is a question whether European money markets at the present time are as favorable to the absorption of American investment securities as home markets.

In connection with repaving requisitions the practice in the City of New York for many years has been to issue fifty-year bonds. As a matter of fact, the life of the average pavement is hardly longer than ten years. Manifestly, fifty-year corporate stock (bonds) should not be issued for this purpose, as on this basis the pavement would have to be renewed at least five times during the lifetime of the original issue, thus storing up for posterity a burden which should be borne by the present generation. Consequently, it has been determined to issue ten-year bonds for the purpose mentioned. 
In view of the city's size and the vast amount of its repaving requirements, this corrective principle will be vital in curtailing the growth of the city debt.

All the measures to which reference has been made have a more or less direct bearing upon the policy of financing the several sinking funds of the City of New York. The corporate stock note gives a basis for financing between bond sales, is a logical sinking fund investment and relieves the surplus moneys of the sinking fund from investments in long-time issues of corporate stock. The correct sinking fund principle is, of course, to amortize through the purchase of old issues rather than to use such funds for the purchase of new issues. Someone has said, "There can be no real sinking fund without surplus." Investment in new issues eats up surplus. Ten-year repaving bonds, corporate stock notes and revenue bills make desirable short-time investments for sinking fund purposes; and as they are all constantly being repaid, the sinking funds are automatically gaining cash strength. While the sinking funds of the City of New York are very large and there will be no appreciable strain upon them for the next quarter of a century, nevertheless, it is manifestly more desirable that investments for sinking fund purposes shall be upon an absolutely sound basis and that, so far as may be practicable, the strict principle of amortization be developed.

The comptroller of the City of New York has organized the Commission of Standardization, which now acts under direction of the Board of Estimate and Apportionment. The work of this commission is developing a uniform system of supply purchase, distribution and control, under standard forms of contracts and specifications. System and business methods are replacing the chaos and wasteful practices which in the past were inevitable through the lack of uniformity in the methods of one hundred different purchasing agents, with the consequent differences in specifications and unit prices. Much constructive work has also been done in the Department of Finance in connection with its accounting methods, so that a strictly business system is being established. All this, in effect, means that there are being introduced in the various branches of municipal activity, so far as possible, the same methods, the same standards and the same requirements that are producing effective results in great private corporations.

In co-operation with a commission appointed by the mayor, 
the comptroller has been accumulating data on what is called "New Sources of Revenue." During the last year a careful study has been made of more than fifty special topics. A new source of revenue has been defined as -first, a decreasing or complete stoppage of leaks in the expenditure of public moneys due to short-sighted and unscientific management; second, an increased income from a present source of revenue; and, third, a latent revenue as yet untapped by the city. Working on these principles, the revenues of all departments of the city, including the county offices within its territorial limits, have been examined in order to ascertain whether such sources of revenue were at their maximum capacity. Analyses have been made of the successes and failures of different methods of raising revenue in other cities of America, Europe, Canada and Australia.

Efficiency in municipal administration and financial reform is largely dependent upon hard, intelligent and constructive work, with the gradual establishment of the principles developed. The most serious difficulty in the way of attainment of the ideal in municipal management is the lack of continuity. The shifting attitude of the voter gives little promise of any change for the better in this respect. It is important, therefore, that the co-operating continuity of civic organizations be made as practical and vital as possible. Their support for this purpose may be regarded as in the nature of double taxation, yet no money devoted to philanthropy could be better applied than in developing efficiency in city government. The civil service should be developed so that there will be a continuing oversight of the clerk or official who is now merely launched upon the sea of service through the medium of a single examination. A system of efficiency records properly prepared and applied would soon produce a corps of civic workers placed with due regard to their ability. The result would be a startling reform in civic activities. While politics must be a continuing element in American life, every effort should be made to choose candidates of inherent ability for their respective positions. 